\title{
Serum gastrin in duodenal ulcer
}

\section{Part IV Effect of selective gastric vagotomy}

\author{
M. G. KORMAN ${ }^{1}$, J. HANSKY, G. A. E. COUPLAND, AND V. H. CUMBERLAND \\ From Monash University Department of Medicine, Prince Henry's Hospital, Melbourne, and the \\ University of Sydney Professorial Subunit in Surgery, Royal North Shore Hospital, Sydney
}

SUMMARY Serum gastrin has been measured in 30 patients following selective gastric vagotomy. Basal serum gastrin was $52 \pm 5 \cdot 7 \mathrm{pg} / \mathrm{ml}$ which was significantly lower than the corresponding level in 50 patients following truncal vagotomy $(84 \pm 7 \cdot 9 \mathrm{pg} / \mathrm{ml})$. After a standard protein meal serum gastrin rose to $136 \pm 8.3 \mathrm{pg} / \mathrm{ml}$ at 60 minutes after the meal. The peak rise above basal levels was significantly lower than that achieved in patients who had undergone truncal vagotomy.

These results complement our previous hypothesis that section of extragastric vagal fibres permits the release of additional gastrin above that expected with the diminution of acid secretion, and hence the decrease in inhibition of gastrin release from the antrum.

Korman, Hansky, and Scott (1972) suggested that truncal vagotomy permits the release of gastrin from the antrum and other sites. They postulated that the mechanism for this release is a combination of diminution in gastric acid secretion and removal of an inhibitor to extragastric gastrin release by section of extragastric vagal fibres.

The validity of this hypothesis has been examined in patients with duodenal ulcer by comparing gastrin levels following selective gastric vagotomy with those following truncal vagotomy. If the hypothesis is correct then selective gastric vagotomy by preservation of extragastric vagal fibres should permit the inhibitor to remain active and prevent the release of extragastric gastrin.

\section{Material and Methods}

After an overnight fast, serum gastrin was estimated in 30 patients who had undergone bilateral selective gastric vagotomy and drainage for active duodenal ulcer. The surgical procedure was as reported by Coupland and Cumberland (1971), the operation having been performed from one month to four years previously.

Six females and 24 males comprised the group

${ }^{1}$ Please address requests for reprints to: M. G. Korman, Monash University Department of Medicine, Prince Henry's Hospital, Melbourne, Victoria 3004, Australia.

Received for publication 11 January 1972. and their mean age was 50 years with a range of 23 to 76 years. The drainage procedure was pyloroplasty in 23 patients and gastroenterostomy in the other seven. Twenty-eight patients had been tested for completeness of vagotomy either at the time of surgery by the electrical stimulator test (Burge, Roberts, Stedeford, and Lancaster, 1969) or postoperatively by the acid secretory response to insulin hypoglycaemia (Hollander, 1946). Only one patient of those tested had evidence of incomplete gastric vagotomy.

Four patients with a complete gastric vagotomy were then further investigated. Each fasting patient was given a standard protein meal (Korman, Soveny, and Hansky, 1971) and peripheral venous blood collected at $-30,0,15,30,45,60,75,90$, 105 , and 120 minutes after protein. The protocol was identical to that reported for truncal vagotomy (Korman et al, 1972). The serum gastrin responses could thus be compared. Serum gastrin was estimated by radioimmunoassay (Hansky and Cain, 1969; Hansky, Soveny, and Korman, 1971b).

Statistical analysis of group means was performed by Student's $t$ test using standard formulae (Snedecor and Cochran, 1968).

\section{Results}

Mean \pm SEM basal serum gastrin in the 30 patients with selective gastric vagotomy and drainage was $52 \pm 5.7 \mathrm{pg} / \mathrm{ml}$ (range 16-116 pg/ml). This level was 


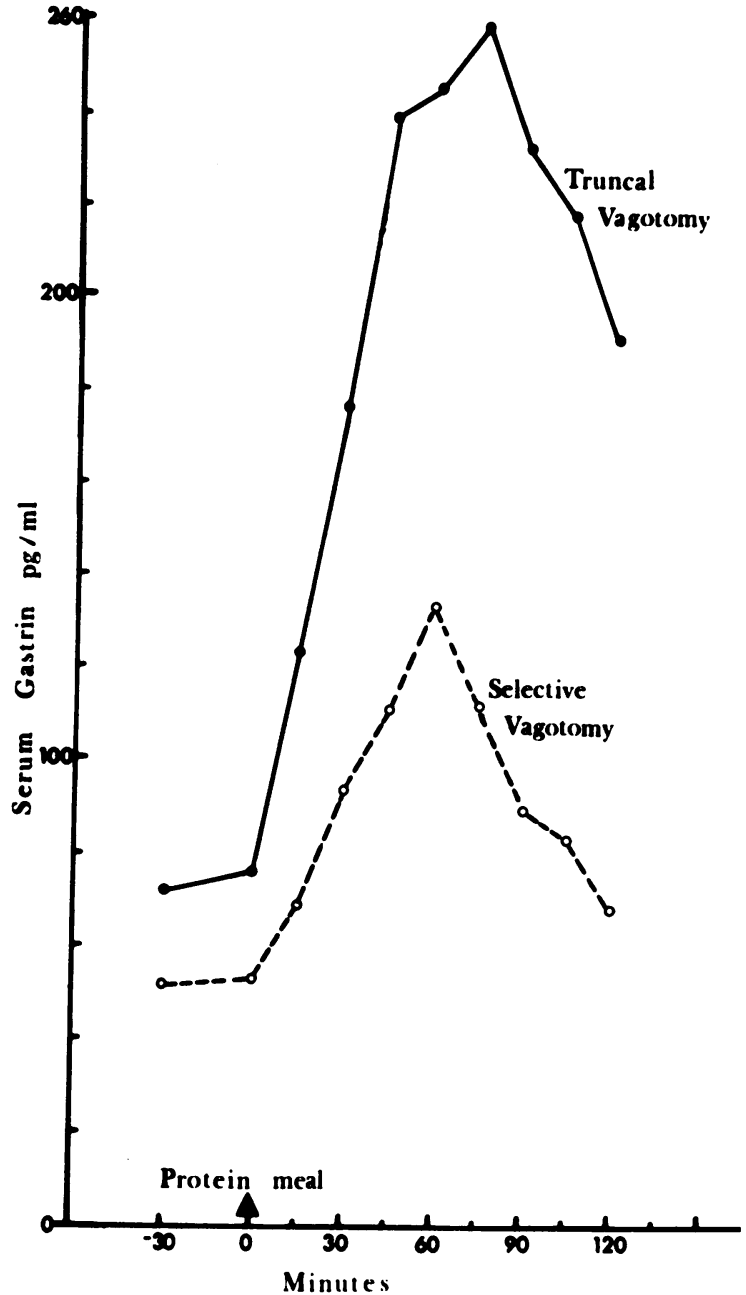

Fig. The mean serum gastrin response to a standard protein meal in duodenal ulcer following truncal vagotomy (five subjects) and selective gastric vagotomy (four subjects).

significantly lower than in a group of 50 patients with truncal vagotomy and pylorectomy whose basal level was $84 \pm 7.9 \mathrm{pg} / \mathrm{ml}(\mathrm{P}<0.005)$, but significantly higher than that previously reported in 72 unoperated patients with duodenal ulcer whose level was $16 \pm 1.5 \mathrm{pg} / \mathrm{ml}(\mathrm{P}<0.0025)$.

There was no difference between patients whose drainage procedure was a pyloroplasty $(52 \pm 6.8$ $\mathrm{pg} / \mathrm{ml})$ and those with a gastroenterostomy $(53 \pm$ $12 \cdot 3 \mathrm{pg} / \mathrm{ml}$ ). No relationship was found between the time since operation and the basal gastrin level. The one patient with evidence of incomplete gastric vagotomy had a basal gastrin level of $16 \mathrm{pg} / \mathrm{ml}$.
The figure compares the serum gastrin response to a protein meal in four patients with selective gastric vagotomy and five patients with truncal vagotomy. In the selective vagotomy group serum gastrin rose significantly from a basal level of $52 \pm 8.5 \mathrm{pg} / \mathrm{ml}$ to a peak of $136 \pm 8.3 \mathrm{pg} / \mathrm{ml}$ at 60 minutes after protein $(P<0.0005)$. The peak rise above basal levels of the truncal vagotomy group was significantly greater than in patients with selective gastric vagotomy $(P<0.025)$.

\section{Discussion}

The basal gastrin level after truncal vagotomy is significantly higher than in unoperated duodenal ulcer patients (84 and $16 \mathrm{pg} / \mathrm{ml}$ respectively). Because induced intragastric neutralization with bicarbonate in the unoperated patients only increased serum gastrin to $45 \mathrm{pg} / \mathrm{ml}$, it was considered that reduction in acid inhibition of gastrin release could not wholly account for the rise in basal gastrin after truncal vagotomy (Korman et al, 1972; Hansky, Korman, Cowley, and Baron, 1971a). It was therefore suggested that vagal section allows the release of additional gastrin from the antrum and other sites, and indeed studies in animals had indicated that this extra release was dependent on section of extragastric vagal fibres (Landor, 1964; Middleton, Kelly, Nyhus, and Harkins, 1965).

The similarity between the basal serum gastrin after selective gastric vagotomy $(52 \mathrm{pg} / \mathrm{ml})$ and that found with induced intragastric neutralization in unoperated patients indicates that the rise in basal gastrin after gastric vagotomy is due to reduction in acid inhibition of gastrin release. The significantly higher basal gastrin level after truncal vagotomy than after selective gastric vagotomy confirms that section of extragastric vagal fibres permits the release of additional gastrin.

Comparison of gastrin responses to a protein stimulus are of interest. The absolute rise in serum gastrin was significantly greater after truncal vagotomy $(185 \mathrm{pg} / \mathrm{ml})$ than after selective gastric vagotomy $(84 \mathrm{pg} / \mathrm{ml})$. These responses complement the difference in basal levels and confirms that substantially more gastrin is released with protein stimulation following section of extragastric vagal fibres.

The role of this additional gastrin released after section of extragastric fibres remains speculative. Certainly acid secretion is similar after both truncal and selective gastric vagotomy (Bank, Marks, and Louw, 1967) so that any effect on acid secretion is insignificant.

Detailed studies of bowel function after selective vagotomy are unavailable but the incidence of 
diarrhoea seems to be less than in truncally vagotomized patients (Frohn, Desai, and Burge, 1968; Williams and Irvine, 1966; Coupland and Cumberland, 1971) although Kennedy and Connell (1969) reported no differences. Perhaps the additional gastrin has a role in the genesis of the diarrhoea as there is some evidence that gastrin affects intestinal motility (Smith and Hogg, 1966). A correlative study of gastrin response to food and the incidence of diarrhoea may provide the answer.

The expert technical assistance of Miss Claire Soveny is gratefully acknowledged. This work was supported by grants from the National Health and Medical Research Council of Australia.

\section{References}

Bank, S., Marks, I. N., and Louw, J. H. (1967). Histamine and insulin-stimulated gastric acid secretion after selective and truncal vagotomy. Gut, 8, 36-41.

Burge, H., Roberts, T. B. L., Stedeford, R. D., and Lancaster, M. J. (1969). Present position of the electrical stimulator test. Gut, 10, $155-159$.

Coupland, G. A. E., and Cumberland, V. H. (1971). Selective gastric vagotomy for peptic ulceration. Med. J. Aust., 1, 954-957.

Frohn, M. J. N., Desai, S., and Burge, H. (1968). Bilateral selective vagotomy in prevention of postvagotomy diarrhoea. Brit. med. J., 1, 481-483.

Hansky, J., and Cain, M. D. (1969). Radioimmunoassay of gastrin in human serum. Lancet, 2, 1388-1390.

Hansky, J., Korman, M. G., Cowley, D. J., and Baron, J. H. (1971 a). Serum gastrin in duodenal ulcer. II. Effect of insulin hypoglycaemia. Gut, 12, 959-962.

Hansky, J., Soveny, C., and Korman, M. G. (1971b). Effect of secretin on serum gastrin as measured by immunoassay. Gastroenterology, 61, 62-68.

Hollander, F. (1946). The insulin test for the presence of intact nerve fibers after vagal operations for peptic ulcer. Gastroenterology, 7, 607-614.

Kennedy, T., and Connell, A. M. (1969). Selective or truncal vagotomy?: a double blind randomized controlled trial. Lancet, 1 , 899-901.

Korman, M. G., Hansky, J., and Scott, P. R. (1972). Serum gastrin in duodenal ulcer. III. Influence of vagotomy and pylorectomy. Gut, 13, 39-42.

Korman, M. G., Soveny, C., and Hansky, J. (1971). Radioimmunoassay of gastrin: Effect of food on serum gastrin evaluated by radioimmunoassay. Gut, 12, 619-624.

Landor, J. H. (1964). The effect of extragastric vagotomy on Heidenhain pouch secretion in dogs. Amer. J. dig. Dis., 9, 256-262.

Middleton, M. D., Kelly, K. A., Nyhus, L. M., and Harkins, H. N. (1965). Selective vagal effects on the intestinal phase of gastric secretion. Gut, 6, 296-300.

Smith, A. N., and Hogg, D. (1966). Effect of gastrin II on the motility of the gastrointestinal tract. Lancet, 1, 403-404.

Snedecor, G. W., and Cochran, W. G. (1968). Statistical Methods. 6th ed., pp. 91-119. Iowa State University Press, Ames, Iowa.

Williams, E. J., and Irvine, W. T. (1966). Functional and metabolic effects of total and selective vagotomy. Lancet, 1, 1053-1057. 